\title{
Canada's reproduction law will have trouble accommodating emerging science
}

$\mathrm{C}$ anada's fertility law is unlikely to accommodate scientific advances like "three-parent invitro fertilization [IVF]," the way the United Kingdom's law has just done - not because we are more circumspect, but because there are gaping holes in our legislation.

The UK's Human Fertilisation and Embryology Act (1990) has shown itself to be robust, says Josephine Johnston, a lawyer and bioethicist at the Hastings Center in Garrison, New York. The UK law has working regulations in place, a strong regulatory body and a commitment to public consultation when changes, like this most recent one, are of substantial public interest. Because of these factors, the UK law has been able to respond to change, including scientific advances, says Johnston.

By contrast, many would say Canada's Assisted Human Reproduction Act, passed in 2004, has been limping its entire life. Only one regulation was ever written. In 2008, Quebec challenged the federal government's right to legislate in a provincial matter health - and in 2010, the Supreme Court responded by striking down much of the federal law. That left mainly prohibitions, such as the one that effectively outlaws "three-parent IVF." In addition, Canada's regulatory body never really got off the ground, and in 2013 it was abolished. Despite the Supreme Court ruling, there has been little action from the provinces, and the result has been a legal and regulatory vacuum.

That does not bode well for accommodating change, says Johnston: "How can you use the act in that fine-grained way if there's no regulatory body and no licensing authority?"

Others have long been concerned that the law relies too heavily on banning rather than regulating. During 2004 Senate hearings, Dr. Calvin Greene of the

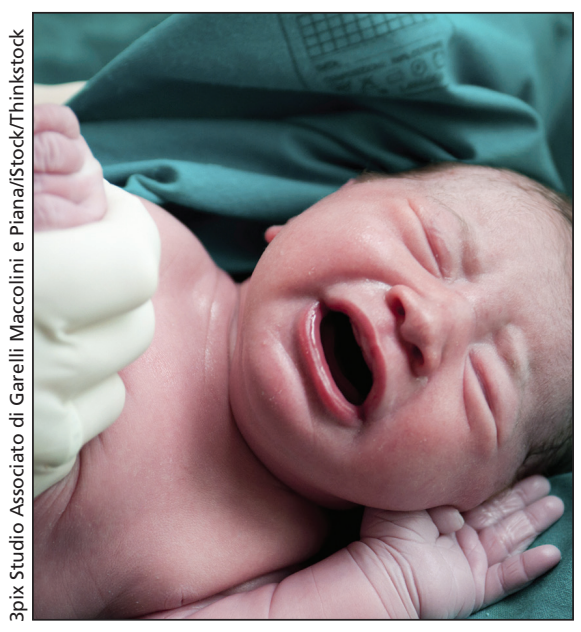

The UK is moving forward with an innovation in reproductive medicine, popularly known as "three-parent IVF."

Regional Fertility Program in Calgary said legal prohibitions would "tie the hands of our researchers" and "deny Canadians the benefits" of medical advances. Now, he says, that is happening. "Canadians will have to go to jurisdictions that permit this. If there's a remedy, why wouldn't you use it?"

Tim Caulfield, a health lawyer at the University of Alberta in Edmonton, also argued at the time that prohibiting scientific advances before you even knew what they were was bad policy. "Who knows in what direction science is going to go?" he says. "Something prohibited may end up having a profound impact. That's the point. We don't know." He thinks the law should be scrapped and replaced with a strong regulatory body and licensing scheme.

The therapy that prompted the amendment to the UK law was developed to help prevent women with mitochondrial diseases from passing mutations on to their offspring. Mitochondria are tiny organelles that power all our cells, and when they malfunction, they cause a variety of disorders, which can be debilitating and sometimes fatal. Mitochondria are always inherited maternally and have their own DNA. The controversial technology involves taking nuclear material from the parent (or in some cases, the parents) and transplanting it into an enucleated donor egg that contains healthy mitochondria. This technique results in a child with DNA from three separate progenitors, a change that will be passed down through generations.

Supporters argue that it will prevent needless suffering for offspring and their families. Critics say not enough is known about the long-term effects for people born through the technique. Others fear it will pave the way for additional heritable genetic modifications, some of which may be for cosmetic rather than medical reasons.

Johnston supports the UK move but says we should come clean about what it means. "We should acknowledge that we are indeed doing things we said we weren't going to do. We are making heritable germ line modifications. We are crossing this line."

She points out that, under the proposed regulations, mitochondrial replacement will be a licensed activity and only a small number of licences will be issued. As few as ten patients a year will be treated in the UK, she says. "It's not that now it's legal anyone can do it."

According to the MitoCanada Foundation, an advocacy group, about 1 in 6000 Canadians has a mitochondrial disorder. Dr. Mark Tarnopolsky, a professor at McMaster University in Hamilton who specializes in mitochondrial disease, questions the fixation on having three sets of DNA in the body.

"Canadians have no problem with bone marrow transplants," he says; no one talks about the fact that recipients get the donor's mitochondrial DNA with the marrow. "Many people walking around do have a mixture of DNA in their bodies." — Alison Motluk, Toronto, Ont.

CMAJ 2015. DOI:10.1503/cmaj.109-5004 